\title{
Hozonkai - fenomen ohranjanja ljudske glasbe in uprizoritvenih umetnosti na Japonskem: primer združenja Kokiriko uta hozonkai*
}

\author{
Klara HRVATIN ${ }^{* * *}$
}

\section{Izvleček}

Članek proučuje fenomen združenj hozonkai za ohranjanje ljudskih pesmi oz. ljudskih uprizoritvenih umetnosti, ki si prizadevajo ohraniti in prenašati japonske ljudske pesmi $\mathrm{v}$ »avtentični«, nespremenjeni obliki. Kot primer enega takšnih združenj in njegovega ravnanja $\mathrm{z}$ ljudskim glasbenim izročilom avtorica obravnava organizacijo in trenutne dejavnosti združenja Kokiriko uta hozonkai - ustanovljenega leta 1951 in zadolženega za ohranjanje in prenos plesne pesmi Kagura mai.

Ob upoštevanju Hughesovih splošnih značilnosti združenj kot osnove avtorica poudari skupne značilnosti, ki jih Kokiriko uta hozonkai deli z večino združenj, hkrati pa osvetli tudi njegove posebnosti. Kokiriko uta hozonkai ima močnejši koncept lokalnosti in ni povsem konservativen glede morebitnih sprememb v glasbi Kagure mai v prihodnosti. Raziskava o združenju Kokiriku uta hozonkai in njegovem "ohranjanju « Kagure mai zastavlja tudi vprašanje, ali hozonkai resnično prenaša starodavno različico pesmi Kagura mai?

Ključne besede: združenje za ohranjanje ljudske glasbe, hozonkai, Kokiriko uta hozonkai, Kagura Mai, Kokiriko, nesnovna kulturna dediščina

\section{Hozonkai - The Phenomenon of Preserving Folk Music and Performing Arts in Japan: The Case of Kokiriko uta hozonkai Association}

\section{Abstract}

The article closely examines the phenomenon of preservation societies or bozonkai, which strives to preserve Japanese folk songs and other folk performing arts in an authentic form or intact without change. As an example of hozonkai's treatment of the folk song, it takes a closer look into organization and current activities of Kokiriko uta bozonkai; a hozonkai

* $\quad$ Pričujoči prispevek je nastal v okviru projekta Vzhodnoazijske zbirke v Sloveniji: vpetost slovenskega prostora v globalno izmenjavo predmetov in idej z Vzhodno Azijo (2018-2021) (št. J7-9429) in programske skupine Azijski jeziki in kulture (št. P6-0243), ki ju iz državnega proračuna financira Javna agencija za raziskovalno dejavnost Republike Slovenije (ARRS).

** Klara HRVATIN, lektorica in asistentka z doktoratom,

Oddelek za azijske študije, Filozofska fakulteta, Univerza v Ljubljani.

Elektronski naslov: klara.hrvatin@ff.uni-lj.si

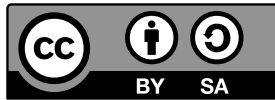


formed in 1951 and in charge of preservation and transmission of song accompanied by dance Kagura mai.

Taking into consideration Hughes' general characteristics of hozonkai as a base, the author points out the commonly shared characteristics which Kokiriko uta hozonkai shares with most preservation societies, but at the same time also shows its particularities. Kokiriko uta hozonkai has a stronger concept of locality and it is not absolutely conservative with respect to possible changes to Kagura mai in the future. Moreover, the research on Kokiriko uta hozonkai and its treatment of Kagura mai raises questions to what extent hozonkai really transmitts the ancient revived Kagura mai?

Keywords: preservation society, hozonkai, Kokiriko uta hozonkai, Kagura mai, Kokiriko, intangible cultural asset

\section{Predstavitev združenj hozonkai in njihove zgodovine}

Hozonkai (保存会) ali združenja za ohranitev ljudskih pesmi so Japoncem morda samoumevna, za tujca oziroma zunanjega opazovalca pa je lahko vpogled v delovanje teh organizacij naravnost osupljiv. $Z$ opredeljevanjem združenja hozonkai so se ukvarjali predvsem strokovnjaki z zahoda. V Malmovi knjigi Japonska glasba in glasbeni instrumenti (Traditional Japanese Music and Musical Instruments, prva izdaja 1.1959) lahko o njih preberemo nekaj vrstic. Opisuje jih kot združenja, "posvečena ,pravilni' izvedbi točno določene pesmi« (Malm 2000, 262). Nettl v svoji knjigi Zahodni upliv na svetovno glasbo (The Western Impact on World Music) hozonkai obravnava na dva različna načina. V prvi vrsti kot odziv na prihod zahodne glasbe, ko se je pojavila potreba po tem, da se starejšo glasbo loči od slednje in se jo na ta način ohrani (Nettl 1985, 125). Avtor poudari, da hozonkai glasbe ne poskuša le ohraniti, pač pa tudi obdržati v nespremenjeni obliki. Poleg tega Nettl tovrstne skupine vidi kot odraz posebnosti glasbene zgodovine Japoncev. Pri njih se namreč glasbene zvrsti med sabo ne mešajo, temveč se »novi materiali $(. .$.$) pridružijo starim in z njimi soobstajajo, pri čemer$ stari ostanejo nespremenjeni« (ibid.).

Širšo in podrobnejšo razlago združenj hozonkai podaja David W. Hughes v svojem delu Tradicionalna ljudska pesem v sodobni Japonski (Traditional Folk Song in Modern Japan), kjer razišče in primerja različna združenja bozonkai in na koncu opredeli skupne značilnosti večine: gre za lokalne, neprofesionalne, nepridobitne organizacije, ki so v splošnem precej konservativne in jih sestavljajo pretežno starejši ljudje (Hughes 2008a, 222-23).

Združenja hozonkai so se začela pojavljati na začetku 20. stoletja oziroma v poznem obdobju Meiji (1968-1911). Beseda hozon (保存, ほぞん), ki pomeni »ohraniti«, se je sprva nanašala na ohranjanje snovnih predmetov, kot so kipi in stavbe. Leta 1897 je - kot prvi zakon, namenjen varstvu umetniških dragocenosti - začel 
veljati Zakon o ohranjanju starih svetišč in templjev, ki je pozneje začel veljati tudi za uprizoritvene umetnosti (Hughes 2008a, 212-14). Uresničevanje/udejanjanje slednjega je podpirala vlada, pri združenjih pa je bila situacija precej drugačna. Specifične literature, ki bi obravnavala hozonkai kot celoto, še ni, zato je treba proučiti vsako združenje posebej. Hughes je prva takšna združenja zasledil v letu 1911, in sicer v mestu Yasugi v prefekturi Shimane (združenje Yasugi-bushi hozonkai), pa tudi na Hokaidu (združenje Oiwake-bushi hozonkai). Namen ustanavljanja teh združenj je bil ohranjanje in širitev pravilnega načina izvajanja lokalnih pesmi, obenem pa tudi reševanje pesmi pred "vulgarnostjo« (Hughes 2008a, 214) gejš. ${ }^{1}$ Enak odnos so imela tudi poznejša združenja, na primer združenje Iso-bushi hozonkai iz leta 1947 in združenje Kaigara-bushi hozonkai iz let 1932/1933. Vendar pa v predvojnem obdobju združenj hozonkai ni bilo veliko. Finančna kriza Showa (昭和金融恐慌 Shōwa Kin'yū Kyōkō) in posledična recesija med letoma 19271931 ter vzpon militarizma so negativno vplivali na uprizoritvene umetnosti; številne so v tem času izginile (ibid., 215) oziroma so bile potisnjene v ozadje. Med drugim, ljudske pesmi takrat niso veljale za primerne, ker naj bi vojake spominjale na domači kraj in ljubezen. Nov val ustanavljanja združenj hozonkai se je začel po vojni, z ohranitvijo ljudske pesmi Esashi oiwake v 1957 ter ljudske pesmi in plesa Yasugi-bushiv 1977 (ibid.).

Hughes poudarja (2008a, 214-22), da je pri razvoju združenj hozonkai zanimiv njihov model poučevanja, ki se zgleduje po sistemu iemoto. Zdi se, da so imeli številni začetniki združenj hozonkai izkušnje s študijem tradicionalnih japonskih glasbenih/umetnostnih zvrsti in so zato predvidevali, da bodo z uporabo takšnega sistematičnega prenosa znanja dosegli, da bo enakega prestiža deležna tudi njihova lokalna pesem. Ustanavljanje združenj hozonkai se je širilo tudi zaradi intenzivnega proučevanja ljudskih pesmi. $\mathrm{V}$ petdesetih letih 20. stoletja se je $z$ njimi ukvarjal zlasti Machida Kashō (1888-1981), ki je tudi sam spodbujal ljudi k oblikovanju združenj hozonkai. Pred njegovimi zgodnjimi raziskavami in zasebnimi gramofonskimi posnetki iz leta 1934 ljudske pesmi pravzaprav sploh niso bile deležne znanstvene obravnave. Svoj zbrani material je pozneje izročil japonski televizijski hiši NHK (Nippon Hōsō Kyōkai), ki je izdala Antologijo japonskih ljudskið pesmi (日本民謡大鑑, Nihon Min'yō taikan, 1944-1988). ${ }^{2}$

1 Gejše naj bi izvajale ljudske pesmi na »svoj« način, s spremljavo shamisena, s čimer naj bi jim dale drugačen značaj glede načina izvajanja (barve glasu), kot tudi samih besedil pesmi; to pa je bilo $\mathrm{v}$ nasprotju s preferencami puristov, ki se niso strinjali z odstopanji od ustaljenih oblik ter izvedb teh pesmi.

2 Antologija japonskib ljudskib pesmi v devetih delih (1944-88), ponovno izdana v letih 1992-94 z 90 zgoščenkami terenskih posnetkov, velja za najpomembnejši vir japonskih ljudskih pesmi. Pesmi so razvrščene glede na svojo funkcijo in vsaka je izčrpno opisana, vključno z družbenim kontekstom, v katerem so jo izvajali. 


\section{Združenja hozonkai in povojni fenomen ohranjanja ljudskih uprizoritvenih umetnosti}

$\mathrm{Na}$ povojno stremljenje $\mathrm{k}$ ohranjanju tako ljudskih kot tudi tradicionalnih umetnosti, ${ }^{3} \mathrm{v}$ katero kot kategorija spada tudi ljudska glasba, je mogoče gledati širše. Ne samo organizacija združenja hozonkai na prefekturnem nivoju - tudi druga vladna ravnanja imajo pomembno vlogo v tem »fenomenu ohranjanja«. Kot lahko vidimo $\mathrm{v}$ spodnji razpredelnici, ki $\mathrm{v}$ časovnem zaporedju prikazuje razvoj na področju ohranjanja ljudskih uprizoritvenih umetnosti, je bil v petdesetih letih 20 . stoletja sprejet nov Zakon o varstvu kulturne dediščine. S tem zakonom so se nekatere od ljudskih uprizoritvenih umetnosti začele vpisovati v register Pomembne nesnovne kulturne dediščine (Jūyō mukei bunkazai hojisha 重要無形文化財保 持者), kar je pomenilo, da je vlada začela določenim posameznikom ali skupinam, ki so bili nosilci ljudskih uprizoritvenih umetnosti, podeljevati naslov živega nacionalnega zaklada. S tem naslovom je oseba ali skupina postala upravičena do posebne zaščite in podpore. $V$ opredelitvi nesnovne kulturne dediščine lahko preberemo, da ta vključuje "folkloro in legende, tradicionalno glasbo, gledališče in ples, svečanosti in festivale, povezane $\mathrm{z}$ življenjskim ciklom, tradicionalno zdravilstvo, npr. terapijo z zelišči, pa tudi tradicionalno rokodelstvo, kot npr. rezbarstvo, lončarstvo, barvanje tkanin in tkalstvo« (Kobinata 2007). V nasprotju s snovno kulturno dediščino, kamor spadajo zgodovinski spomeniki ali arheološke najdbe, so pri nesnovni kulturni dediščini "nosilci človeška telesa in duše, preko katerih se ta prenaša« (ibid.). $V$ tem kontekstu je zanimivo tudi poimenovanje »živi nacionalni zaklad« (ningen kokubō 人間国宝), ki ga vlada podeli določenim posameznikom, pa naj bodo to mojstri predstav bunraku, kabuki ali festivalov matsuri - na primer mojster shakuhachija, Gorō Yamaguchi (1933-1999), ali mojster bobna taiko, šintoistične glasbe in plesa kagura in drugih zvrsti, ki so del slavnosti festivalov (matsuri 祭り), Matsumoto Gennosuke (1924-), ali pa mojstri obrti (lesorez, izdelovanje papirja, lončarstvo). Ta naziv jim nalaga dolžnost ohranjati svoje veščine, tehnike in umetniški izraz nedotaknjene, nespremenjene in brez vplivov z zahoda.

Dve leti po uvedbi Zakona o varstvu kulturne dediščine je bil ustanovljen Tokijski nacionalni raziskovalni inštitut za kulturno dediščino. Imel je zelo pomembno vlogo pri izvajanju raziskav, katerih namen je bil zbirati informacije o ohranjanju

3 Japonske ljudske upodabljajoče umetnosti (minzoku geinō) so del širše skupine upodabljajočih umetnosti oziroma t. i. tradicionalnih upodabljajočih umetnosti (dento geinō). Izvajajo se na številnih ritualnih in sekularnih prireditvah po Japonski. Po klasifikaciji, ki jo je uvedel Yasuji Honda, in jo uporablja tudi Agencija za kulturne zadeve pri vpisovanju upodabljajočih umetnosti v register Pomembne nesnovne kulturne dediščine, jih v grobem delimo na glasbo, posvečeno bogovom (kagura), glasbo, povezano s poljedelskimi ciklusi (dengaku), glasbo oz. plese, značilne za (spektakularne) procesije (furyū), narativne oblike in prireditve ob praznovanjih (katarimonolshukufukugei) ter oblike, izpeljane iz zahodnih odrskih prireditev. Za podrobnejšo razdelitev glej Lancashire 2011, 6-8. 
umetniških del in zvrsti in s tem pomagati pri njihovem ohranjanju in promociji. Pozneje, leta 1968, je bila ustanovljena tudi Agencija za kulturne zadeve (Bunkachō 文化庁) kot edina agencija, ki je za ohranjanje in promocijo ljudskih uprizoritvenih umetnosti skrbela na nacionalnem nivoju (ibid.).

Ob sprejetju zakona leta 1950 so bile vpeljane naslednje kategorije zaščitenih vsebin: snovna kulturna dediščina (dela s področja likovne umetnosti, stavbe in drugi objekti), spomeniki, vključno z zgodovinskimi znamenitostmi, kraji s slikovitimi naravnimi znamenitostmi in pa na novo vpeljani koncept nesnovne kulturne dediščine, kot jo predstavljajo odrske umetnosti in glasba (Kakiuchi 2014, 4). Od takrat je bil zakon deležen več sprememb. Zdaj vključuje: 1) snovno kulturno dediščino, 2) nesnovno kulturno dediščino, 3) ljudsko kulturno dediščino, 4) spomenike, 5) kulturne krajine in 6) skupine stavb zgodovinskega pomena. Treba je omeniti, da poleg omenjenih zakon zdaj vključuje tudi poglavje Tradicionalne tehnike za obranjanje kulturne dedišcine, ki so bistvene za ohranjanje in konzerviranje omenjene kulturne dediščine, ter poglavje Zakopana kulturna dediščina. ${ }^{4}$

Združenja hozonkai v obliki nevladnih organizacij segajo v čas po drugi svetovni vojni, ko so ta združenja izvajala ljudske umetniške oblike in s tem skrbela za njihovo ohranjanje in promocijo. To, da so bozonkai nevladne organizacije, v pravnem smislu pomeni, da so jih ustanovili zasebniki ali organizacije brez podpore ali zastopanja s strani vlade.

Tabela 1: Kratka zgodovina prizadevanj za ohranitev ljudskih uprizoritvenih umetnosti in ustanoviter združenj hozonkai ${ }^{5}$

\begin{tabular}{|c|c|}
\hline Leto & Dejavnosti za ohranitev ljudske uprizoritvene umetnosti \\
\hline pred obdobjem Meiji & Uprizoritvene umetnosti cvetijo. \\
\hline 1879 & $\begin{array}{l}\text { Ustanovitev Oddelka za proučevanje glasbe } \\
\text { (Ongaku torishirabe gakari) v okviru } \\
\text { Ministrstva za izobraževanje. }\end{array}$ \\
\hline & Začetki uvoza zahodne glasbe. \\
\hline 1887 & $\begin{array}{l}\text { Ongaku torishirabe gakari se preimenuje v Tokyo } \\
\text { ongaku gakko (Narodna univerza likovne umetnosti } \\
\text { in glasbe; od leta } 1949 \text { Fakulteta za glasbo). } \\
\text { - Prevzame glavno vlogo pri promoviranju zahodne glasbe na } \\
\text { Japonskem. } \\
\text { - Tradicionalne/ljudske uprizoritvene umetnosti se zanemarja. }\end{array}$ \\
\hline
\end{tabular}

4 Od zgoraj omenjene kulturne dediščine se v nesnovno kulturno dediščino uvrščajo naslednje kategorije: 1. nesnovna kulturna dediščina, 2. nesnovna ljudska kulturna dediščina in 3. tradicionalne konservatorske tehnike. Več o tem v naslednjih virih: Agency for Cultural Affairs 2015, 2-3; Kakiuchi 2014, 7.

5 Zgodovinska razpredelnica je sestavljena iz povzetkov oz. skupkov različnih virov, kot so Kobinata 2007, Kakiuchi 2014, Agency for Cultural Affairs 2015. 


\begin{tabular}{|c|c|}
\hline Leto & Dejavnosti za ohranitev ljudske uprizoritvene umetnosti \\
\hline $\begin{array}{l}\text { 1950, sprejetje Zakona o varstvu } \\
\text { kulturne dedišcine }\end{array}$ & $\begin{array}{l}\text { Ponovno se začne razmišljati o ohranjanju in promociji ljud- } \\
\text { skih uprizoritvenih umetnosti. } \\
\text { - Vlada lahko podeli status nosilca tradicije. } \\
\text { - Lokalne oblasti lahko izvajajo javne predstave. } \\
\text { Nekatere ljudske uprizoritvene umetnosti so razglašene za po- } \\
\text { membno nesnovno kulturno dediščino in živi nacionalni zaklad. }\end{array}$ \\
\hline 1951 & $\begin{array}{l}\text { Začne se ustanavljanje združenj hozonkai na nivoju prefektur } \\
\text { (oz. nevladnih organizacij za ohranjanje in promocijo ljudskih } \\
\text { uprizoritvenih umetnosti). }\end{array}$ \\
\hline 1952 & $\begin{array}{l}\text { Tokijski nacionalni raziskovalni inštitut za kulturno dediščino; } \\
\text { - proučevanje številnih vidikov uprizoritvenih umetnosti. }\end{array}$ \\
\hline $\begin{array}{l}\text { Zakon o varstvu kulturne dedišcine, } \\
\text { amandma iz leta } 1954\end{array}$ & $\begin{array}{l}\text { Razširitev sistema na kategorijo Ljudski materiali; } \\
\text { - ustanovitev sistema za označevanje pomembnih snovnib ljud- } \\
\text { skih materialov, ločeno od snovne kulturne dediščine. }\end{array}$ \\
\hline $\begin{array}{l}\text { Zakon o varstvu kulturne dedišcine, } \\
\text { amandma iz leta } 1968\end{array}$ & $\begin{array}{l}\text { Oblikuje se Bunkachō-Agencija za kulturne zadeve; je edina } \\
\text { agencija za ohranjanje in promocijo tradicionalnih/ljudskih } \\
\text { uprizoritvenih umetnosti, ki deluje na državnem nivoju. }\end{array}$ \\
\hline $\begin{array}{l}\text { Zakon o varstvu kulturne dediščine, } \\
\text { amandma iz leta } 1975\end{array}$ & $\begin{array}{l}\text { Kategorija Ljudska kulturna dediščina - ljudski materiali je prei- } \\
\text { menovana v Ljudska kulturna dediščna; } \\
\text { - vzpostavitev sistema za označevanje pomembne snorne ljudske } \\
\quad \text { kulturne dedišcine in pomembne nesnovne ljudske kulturne dedisčine. }\end{array}$ \\
\hline 2001 & $\begin{array}{l}\text { Temeljni zakon za promocijo kulture in umetnosti; } \\
\text { - promocija kulture in umetnosti. }\end{array}$ \\
\hline $\begin{array}{l}\text { Zakon o varstvu kulturne dediščine, } \\
\text { amandma iz leta } 2004\end{array}$ & $\begin{array}{l}\text { Širitev kategorije Ljudska kulturna dediščina; } \\
\cdot \quad \text { dodajo ji ljudske tehnike. }\end{array}$ \\
\hline
\end{tabular}

\section{Združenje Kokiriko uta hozonkai in njegova vloga pri ohranjanju pesmi Kagura mai}

\section{Združenje Kokiriko uta hozonkai}

Združenje Kokiriko uta hozonkai je zadolženo za ohranjanje plesne pesmi ob spremstvu inštrumenta sasara z imenom Kokiriko uta (筑子歌) in šintoistične obredne plesne pesmi Kagura mai (神楽舞). Kokiriko pomeni dobesedno "poljski ples«, ki so ga plesali v 13. in 14. stoletju v času sejanja in žetja riža ter ob drugih poljedelskih slavnostih, uta pa pomeni "pesem«. Kot že rečeno, se ljudje pridružijo plesu in petju pesmi Kokiriko ob glasnem spremstvu sasare, glasbenega inštrumenta iz bambusa (glej sliko 1), ki naj bi ga za izvajanje te pesmi uporabljali že v preteklosti. Kagura mai pa je pesem religioznih festivalov in obredov (glej sliko 12$)^{6}$, ki so jo včasih peli tudi v obliki ljudske pesmi Maimai, in sicer ob določenih priložnostih, ko so fantje in dekleta, držeč se za roke,

6 Kagura je splošen izraz za šintoistično glasbo in plese, ki so ključni za ritualno versko prakso šintoizma. Dobesedno bi lahko izraz kagura prevedli kot "glasba bogov«. Lahko jo razdelimo na mikaguro (kagura, ki se izvaja na cesarskem dvoru), okaguro (kagura v državnih šintoističnih svetiščih) in satokaguro (kagura za dogodke v lokalnih šintoističnih svetiščih). Ne glede na različne zvrsti se navadno uporablja le ime kagura. V našem primeru spada kagura $v$ okvir lokalnega festivala (matsuri), ki je značilen za kmetijske družbe pri obredih rodovitnosti, v katerih se letni časi praznujejo s 
drug za drugim plesali v krogu; na ta način so nekateri dobili priložnost, da si izberejo partnerja in se poročijo. ${ }^{7}$ Danes se je religiozna vloga pesmi prepletla oz. nadgradila s folklornimi in turističnimi dogodki (glej sliko 4-5).

Obe pesmi, Kokiriko in Kagura mai, pa tudi, kot bomo videli, samo združenje, ki ju ohranja, izvirajo iz majhne vasi Kaminashi (上梨) v Gokayami (五箇山) ${ }^{8}$, v jugovzhodnem delu prefekture Toyama. Zlasti med lokalnimi festivali pesmi izvajajo v svetišču Hakusangū. Regija Gokayama je poznana po hišah v slogu gasshō-zukuri (合掌造り, dobesedno slogu »sklenjenih rok«, ki je razviden iz same strukture streh teh hiš v obliki visokih trikotnikov), še pomembnejši pa je njen sloves zakladnice ljudskih pesmi in plesov. Ena od zanimivih legend o tem kraju pravi, da so se v 12. stoletju na tem območju naselili pobegli bojevniki klana Taira, ki naj bi tja prinesli najstarejšo ljudsko pesem na Japonskem - zgoraj omenjeno pesem Kokiriko uta oziroma Kokiriko-bushi (筑子節).

Kokiriko uta hozonkai ali Ecchü Gokayama kokiriko hozonkai je leta 1951 (v 26. letu obdobja Shōwa) ustanovila skupina ljudi iz Kaminashija pod vodstvom g. Takachika Takakuwe. Je tudi del združenja petih združenj hozonkai v Gokayami, tako imenovanega Združenja združenj za ohranjanje pesmi in plesov za področje Echū Gokayame (Echū Gokayama Min'yō minbu hozondan rengōkai 越中五箇山民謡民舞保存団 連合会). Eno leto po ustanovitvi združenja Kokiriko uta hozonkai (1952) je radijski oddelek NHK po naročilu Komisije za varstvo kulturne dediščine posnel pesmi Kokiriko in Kagura mai. Od leta 1965 je Kokiriko ena od ljudskih pesmi, ki jih učijo v tretjem in četrtem razredu osnovne šole. Nazadnje je bila leta 1973 Kokiriko s pripadajočim plesom ter skupaj s Kaguro mai razglašena za nesnovno kulturno dediščino. Leta 1974 je Agencija za kulturne zadeve posnela zbirko dokumentarnih posnetkov Kiroku eizōshu (記録映像集), kjer lahko najdemo tudi prvi videoposnetek izvedbe pesmi Kokiriko uta in Kagura mai. Temu je sledila uvrstitev teh ljudskih pesmi na zgoščenke, kot je na primer Ljudske pesmi iz Gokayame (Gokayama no Min'yō 2002) idr. Vse različice na zgoraj omenjenih medijih je izvedlo združenje (glej sliko 12) Kokiriko uta hozonkai, katerega ime je sestavljeno iz osrednje pesmi Kokiriko uta, ki jo ohranja. V članku se bomo posvetili predvsem ohranjanju pesmi Kagura mai, obe pesmi, ki imata naziv nesnovne kulturne dediščine, pa navadno v "paru« izvajajo tudi na prireditvah.

praznovanjem rodovitnosti, blagoslavljanja ali prečiščevanja.

7 Izvor takšnih dogodkov je najverjetneje povezan s staro japonsko tradicijo, imenovano utagaki, ko so se mladi zbirali, peli, plesali in se spogledovali do jutranjega svita med glavnimi festivali (Nihon minyō taikan, 226-29).

$8 \mathrm{Z}$ imenom Gokayama (五箇山) so prvotno poimenovali regijo petih dolin; Kaminashidan (上梨 谷), Shimonashidan (下梨谷), Odan (小谷), Togadan (利賀谷) in Akaodan (赤尾谷). Od obdobja Meiji naprej je to skupen izraz za tri vasi, in sicer vasi Taira mura (平村), Kamitaira mura (上平 村) in Toga mura (利賀村), ki administrativno spadajo v okrožje Higashitonami-gun (東研波郡) prefekture Toyama (Misumi 1992, 2-3). 


\section{Kagura mai: klasifikacija in glasbene značilnosti}

Kagura mai je znana tudi pod imenom Maimai (まいまい). Sodeč po virih, ki omenjajo pesem Maimai, po informacijah o pesmi Maimaiv Antologiji japonskih ljudskih pesmi in po izjavah ljudi iz Gokayame, se za isto pesem včasih uporablja ime Kagura mai, včasih pa Maimai; nič ne kaže na to, da bi bilo treba med tema dvema imenoma razlikovati. Ustno izročilo kaže, da je Kagura mai prvotno obstajala predvsem kot del Maimai, pozneje pa se je osamosvojila v obliki kagure, kot jo poznamo danes; ni sicer jasno, kdaj točno se je to zgodilo (Nibon min'yō taikan 226-29).

Po najbolj razširjeni klasifikaciji ljudskih pesmi min'yō (民謡 $)^{10}$ lahko Kaguro mai štejemo za plesno pesem, ki spremlja kaguro. Nadalje, po Mamiyevi etnološki klasifikaciji, Japonske ljudske pesmi - etnološka klasifikacija (Mamiya 1998), je Kagura mai klasificirana kot pesem verskih festivalov in ceremonij, natančneje šintoistična obredna pesem. Glede na elemente kot so ples, rekviziti ${ }^{11}$, kostumi $^{12}$ in religiozni podtoni, jo lahko klasificiramo tudi kot eno od zvrsti ljudske uprizoritvene umetnosti (minzoku geinō 民俗芸能).

Njene poglavitne glasbene značilnosti so glasbena lestvica oz. modus ritsu, tridelna oblika (A-B-A'), strofična oblika, kar pomeni da imajo vsi verzi besedila enako melodijo in glasbeno podlago, ter dvodobni takt. Vsi verzi besedila imajo enako število zlogov (sedem). Besedilo orisuje štiri letne čase. Rime, ki bi nas vodila od začetka do konca pesmi, ni. Vsak letni čas je predstavljen s simbolom oziroma elementom, ki se s tem letnim časom povezuje. V tretjem verzu pesmi Kagura Mai se, na primer, pojavi princesa jeseni, Tatsuta, pa tudi rdeče listje in jeleni - vse to so prispodobe jeseni:

9 Klasifikacija in glasbene značilnosti pesmi Kagura mai so povzete iz Hrvatin 2010, 112-14.

10 Min'yō (民謡) lahko prevedemo kot »ljudsko pesem«. Gre za neposredni japonski prevod iz nemškega izraza za ljudsko pesem Volkslied, ki se je začel uporabljati konec 19. stoletja, v času, ko se je začela Japonska zgledovati po zahodu. Japonci so pred tem navadno uporabljali različne izraze, med katerimi je bil najpreprostejši tisti, ki je zaobjemal širši spekter vokalne glasbe, med drugimi izraz uta ali pesem. Min'yō se navezujejo na določena kmečka opravila oziroma obrti in so se navadno pele ob opravljanju le-teh, nekatere so imele vlogo razvedrila, spremljave k plesu ali pa so bile vključene v verske običaje. Za natančnejšo razlago glej Hughes 2008, 14-19.

11 Pri plesu v rokah držijo pahljačo iz ciprese, pri čemer več pozornosti posvečajo "postankom in gibom, kot pa pretiranemu premikanju nog« (Ono, 45; Ecchū Gokayama no dentō). Prvotno je ples izvajala miko-san (巫女さ $h$, šamanka oz. pomočnica v šintoističnem svetišču) (ibid.).

12 Kostum sestavljajo nagaeboshi (長烏帽子, visok klobuk iz svile in japonskega papirja), suikan (水 干, zgornji bel kimono) in hibakama (緋袴, živordeče deljeno krilo). Obleka je podobna dvornim oblačilom iz obdobja Heian (794-1185). Lasje plesalke visijo zadaj izpod klobuka in so povezani z živordečim trakom. V svetišču nosijo nogavice tabi (足袋, bele, ločene pri palcu, ki se jih navadno uporablja tako pri ljudskih kot tudi tradicionalnih uprizoritvenih umetnostih), ki se običajno uporabljajo tudi pri ceremonijah. 
秋は龍田姫峰山越えて候ばへ、

山の紅葉も、鹿も啼き向ふ候ばへ

Aki wa Tatsuta hime (na), mine yama koete (sōrabae), yama no kōyō mo (na), shika mo naki mukafu (sōrabae).

\section{Jeseni}

je princesa Tatsuta odšla

čez vrh gore.

V rdečem jesenskem listju na gori

se oglašajo jeleni.

Flute

\section{KAGURA MAI}
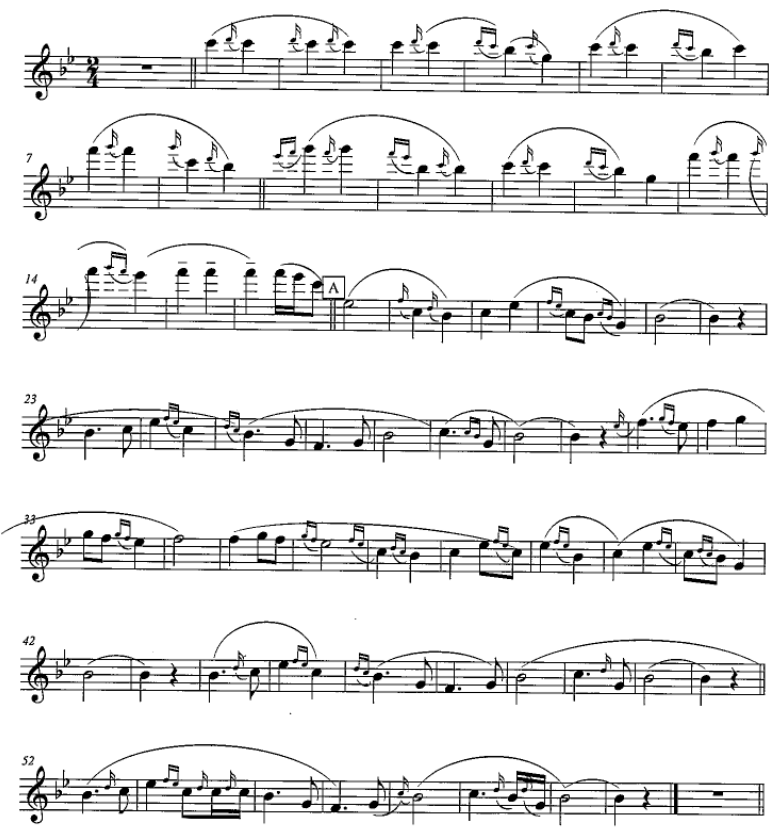

Transkripcija pesmi Kagura Mai, del za flavto shinobue ${ }^{13}$

13 Transkripcija je zapisana po 1. zvočnem zapisu pesmi iz leta 1952. Spisana je bila v študiju skladatelja (in vodje pihalnih orkestrov) Josipa Grgasoviča. Inštrumenti, uporabljeni v kaguri, so približani zahodnim inštrumentom, in sicer japonska flavta shinobue njeni zahodni različici ter bambusove paličice kokiriko no take paličkam. 
Glasbo, ki spremlja to pesem, izvaja majhna skupina glasbenikov hayashi, ki običajno igrajo na naslednja glasbila: boben taiko ali biradaiko (太鼓 ali 平太鼓; boben, po katerem se bobna s palico), flavta fue (笛) ali shinobue (篠笛), par majhnih bakrenih činel dōbyōshi (銅拍子) in strgalo bōzasara (棒ザサラ), imenovano tudi surizasara (摺りザサラ). V izvedbi Kagure mai, posneti leta 1951, je slišati tudi tako imenovani kokiriko no take (筑子の 竹). To je bil običajno inštrument uličnih glasbenikov, izdelan iz dveh bambusovih vršičkov (velikosti $22,5 \times 1-1,5 \mathrm{~cm}$ ), igra pa se ga s konicami prstov, tako da se vršička obrača in udarja drug ob drugega na njunih koncih.

\section{KAGURA MAI}

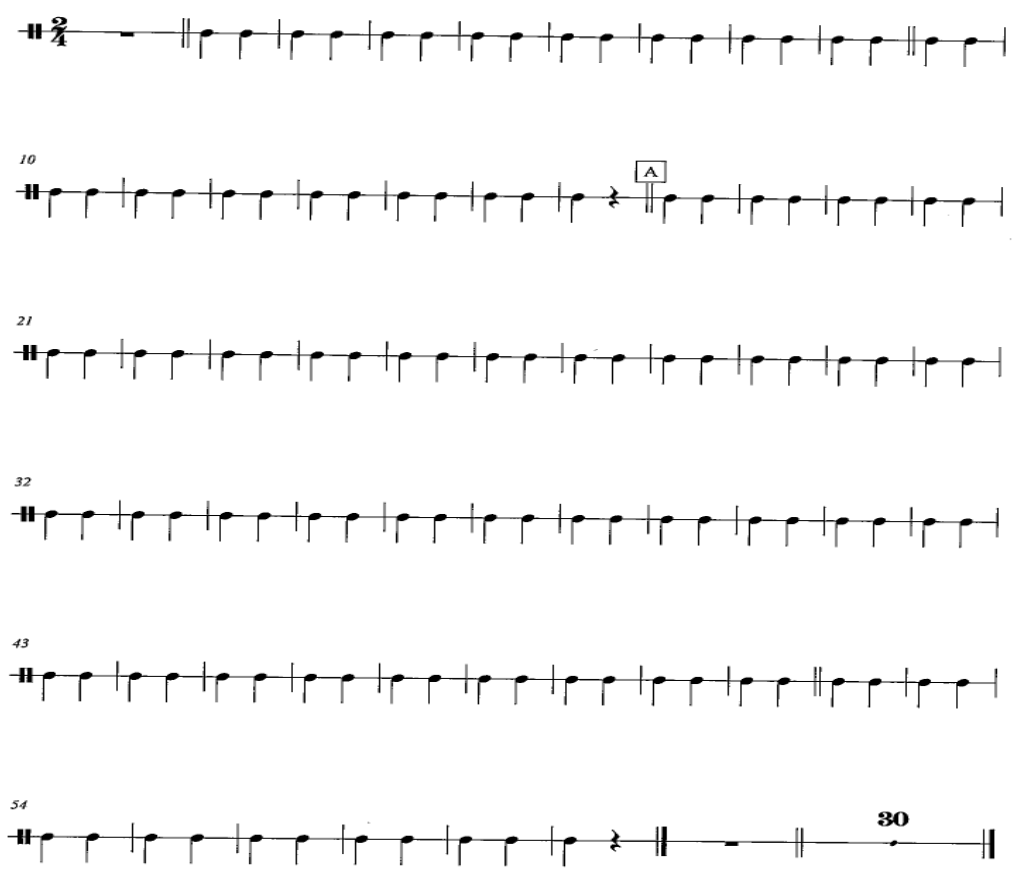

Transkripcija pesmi Kagura Mai, del za bambusove palcke kokiriko no take $e^{14}$

14 Glej opombo 13. 


\section{Hughesova karakterizacija združenj hozonkai in združenje Kokiriko uta bozonkai}

Na podlagi proučevanja različnih združenj hozonkai je Hughes formuliral splošno "podobo« teh organizacij; če na kratko povzamemo, so večini združenj bozonkai skupne naslednje značilnosti:

1. So lokalne organizacije, namenjene ohranjanju lokalnih pesmi. Običajno se identificirajo $\mathrm{z}$ določeno vasjo, krajem ali delom mesta.

2. So amaterske skupine, ki niso osredotočene na materialne koristi. Resda včasih obstajajo tudi izjeme.

3. Nagnjene so h konservativizmu in se upirajo spremembam $v$ glasbi, besedilu, plesu, kostumih itn., čeprav so izjeme tudi na tem področju. Ko dejansko pride do sprememb, želijo imeti nad njimi nadzor. Na tej točki utegne priti do konflikta med združenji hozonkai in profesionalnimi urbanimi izvajalci.

4. Člani so pogosto zelo stari. Številna združenja hozonkai so bila osnovana $\mathrm{v}$ petdesetih in šestdesetih letih 20. stoletja $\mathrm{z}$ namenom obujanja vaške tradicije, ki je zamrla $v$ tridesetih in štiridesetih letih 20. stoletja. Učitelji so zato običajno precej stari. Kot je bilo že omenjeno, [...] je mlajše generacije težko navdušiti nad lokalnimi ljudskimi pesmimi. Veliko lažje jih je privabiti, če je zraven še živahen ples.

5. Člani pogosto upajo, da bo njihova priljubljena pesem (ali več pesmi) dosegla vidnost na nacionalni ravni. [...] Hkrati pa se velikokrat pritožujejo nad tem, kako neizogibno je, da profesionalni izvajalci njihove pesmi na takšen ali drugačen način spremenijo (Hughes 2008a, 222-23).

Z vidika zgoraj omenjenih skupnih značilnosti združenj hozonkai bo predstavljena organizacija Kokiriko uta hozonkai.

Gre za lokalne organizacije, namenjene obranjanju lokalnib pesmi. Običajno se identificirajo z določeno vasjo, krajem ali delom mesta.

$Z$ vidika prve značilnosti združenj po Hughesu je Kokiriko uta hozonkai lokalna organizacija, ki si prizadeva za ohranjanje lokalnih pesmi in plesov. Lokalno v tem primeru pomeni, da vsi njeni člani pripadajo približno sto prebivalcem vasi Kaminashi Tairamura; med seboj se poznajo, živijo drug poleg drugega in imajo staro in lepo navado sovaščane obiskovati osebno, namesto da bi uporabili telefon ali druge posredne načine komunikacije. Srečanja članov hozonkai se odvijajo običajno v hiši katerega od članov. Njihovo organizacijo in dejavnosti sponzorirajo pretežno člani sami in vaščani. 

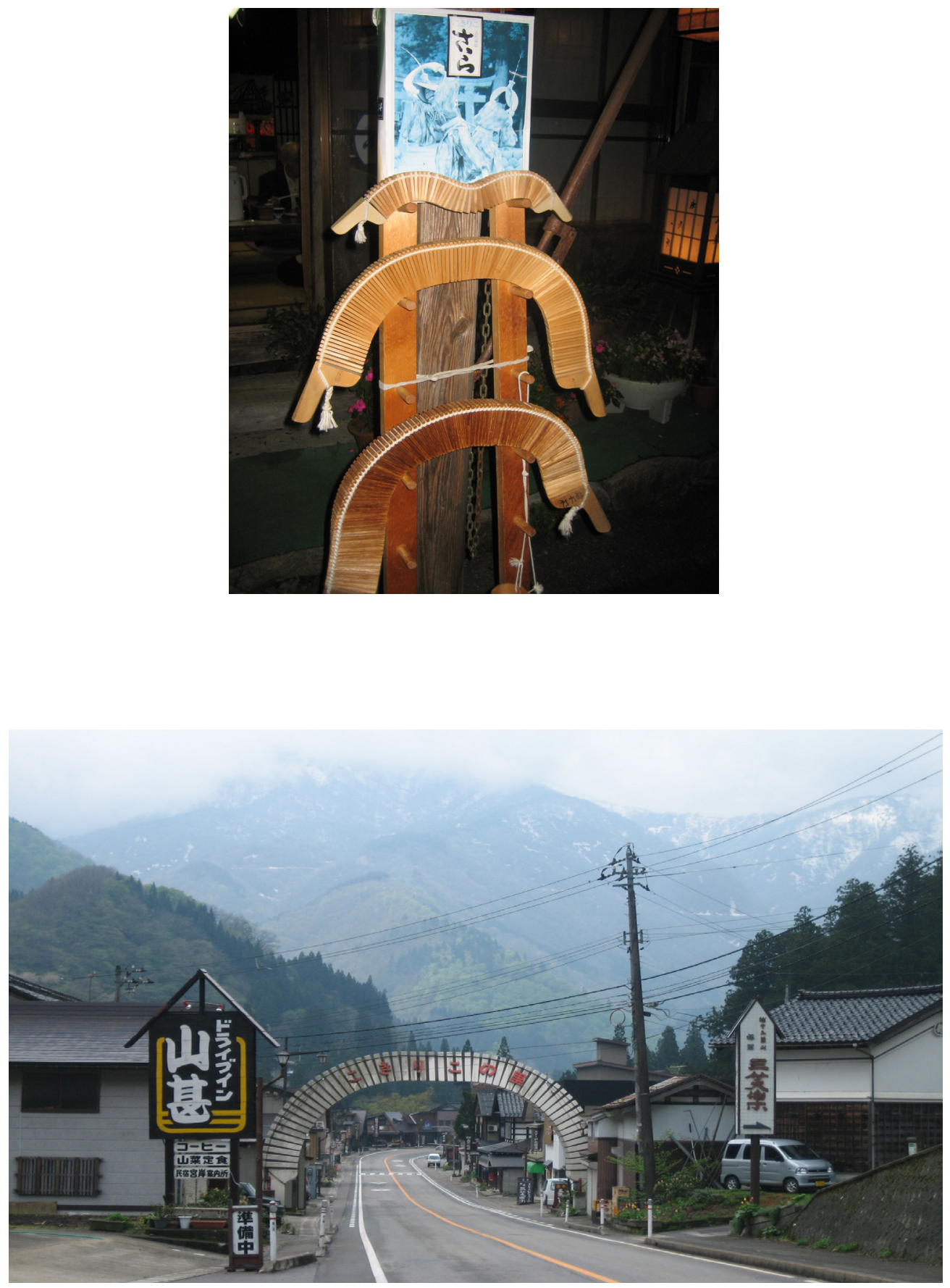

Sliki 1 in 2: Festival Kokiriko prirejajo 25. in 26. septembra. Obiskovalci se preizkusijo v plesu $\mathrm{z}$ inštrumentom sasara. (Vir: Klara Hrvatin) 

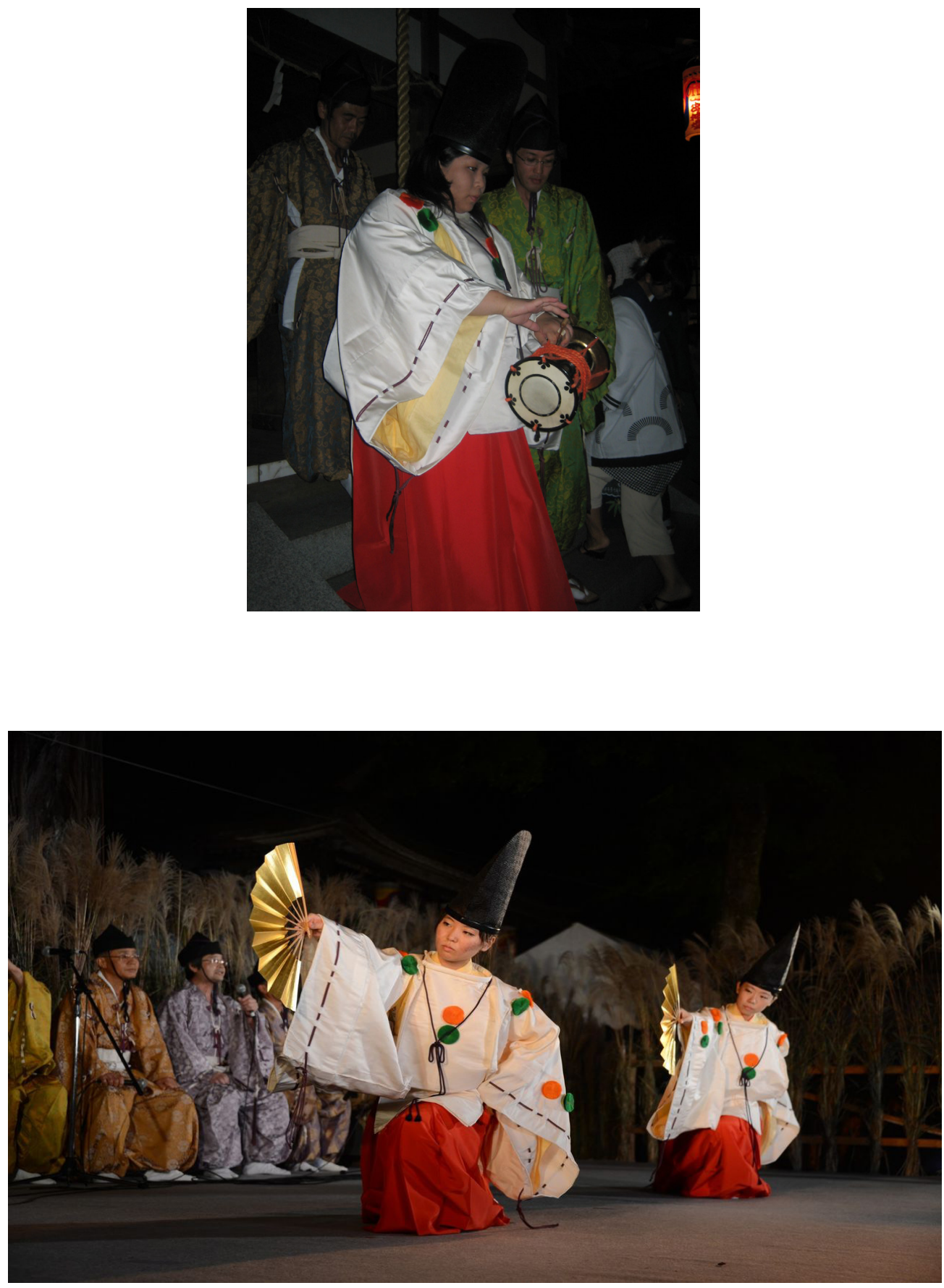


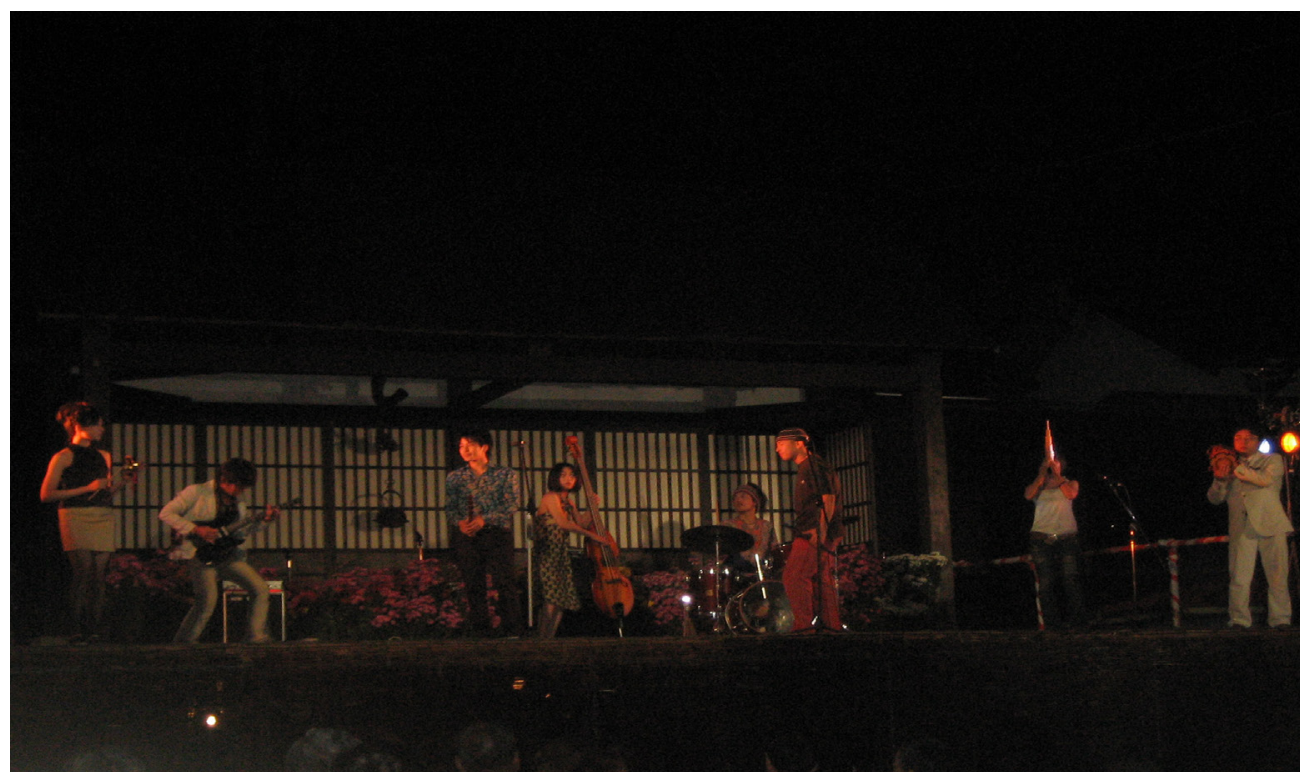

Slike 3, 4 in 5: Kagura mai se med festivalom Kokiriko izvaja dvakrat: ob daritvi v svetišču Hakusangu in na odru med večerno predstavo. (Vir: Klara Hrvatin)

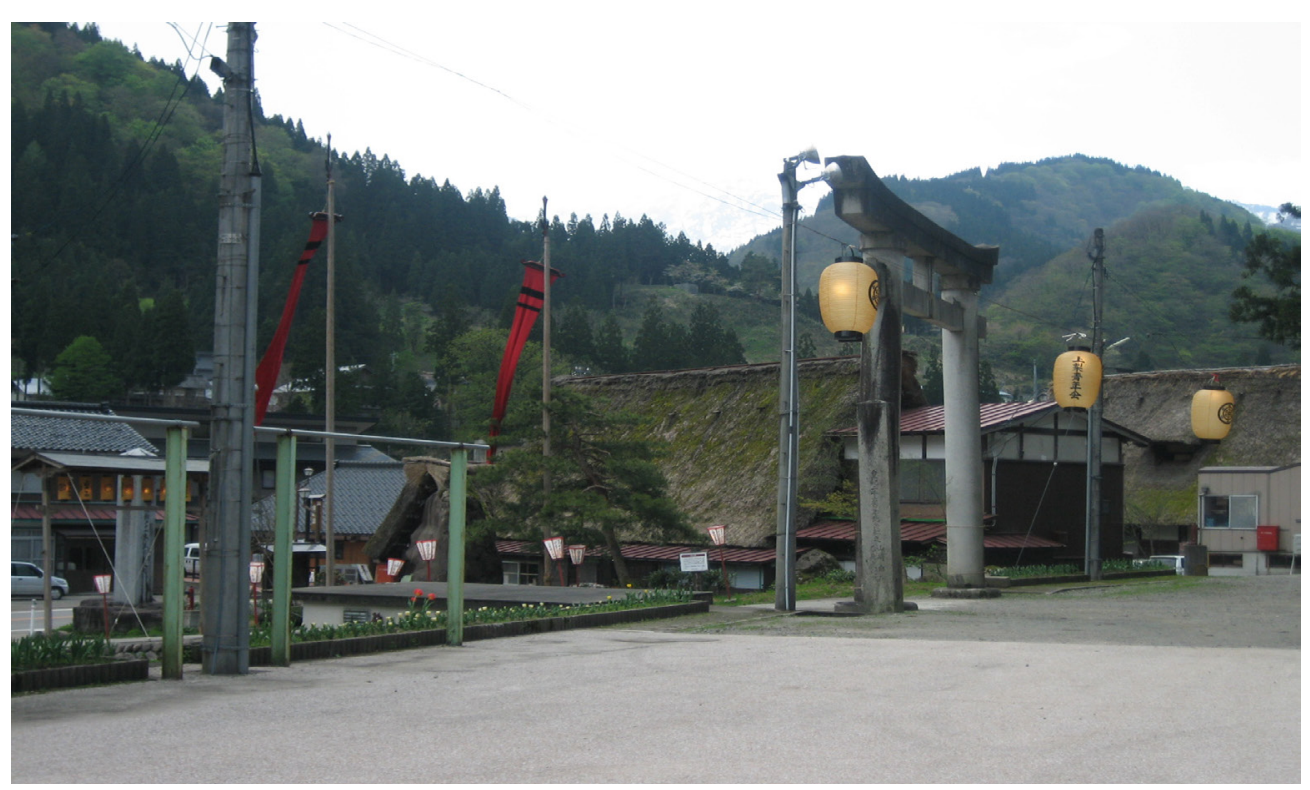



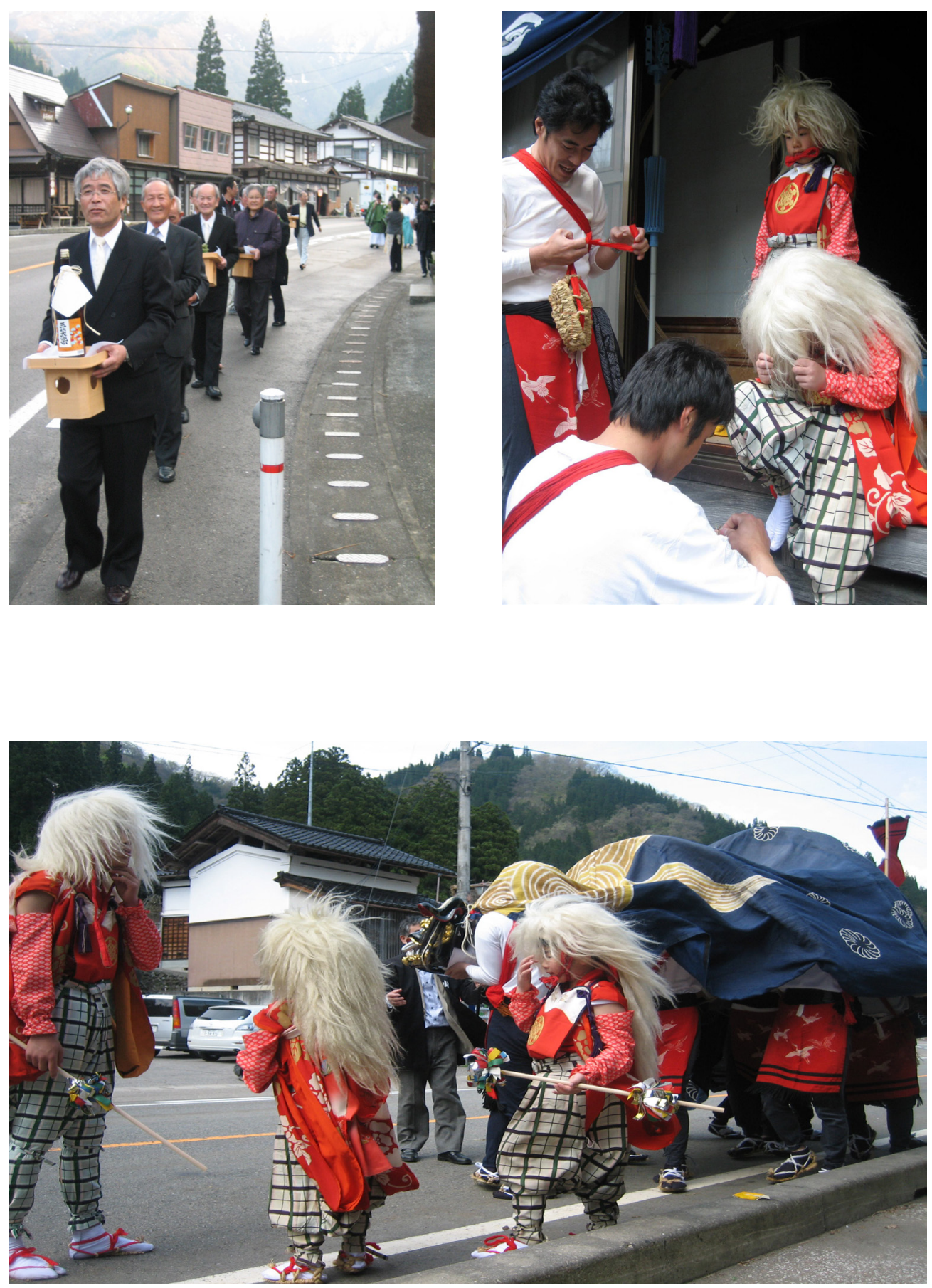

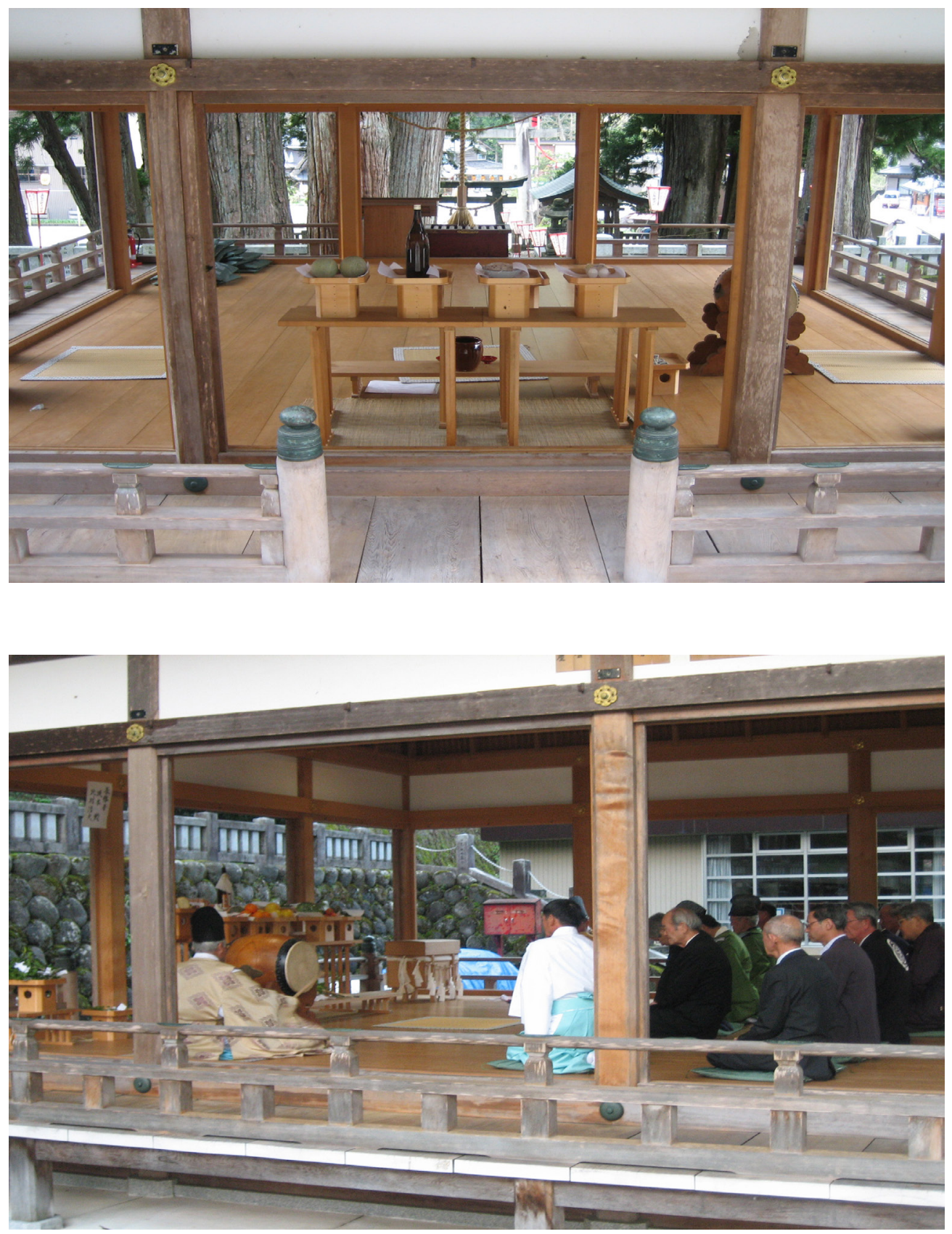


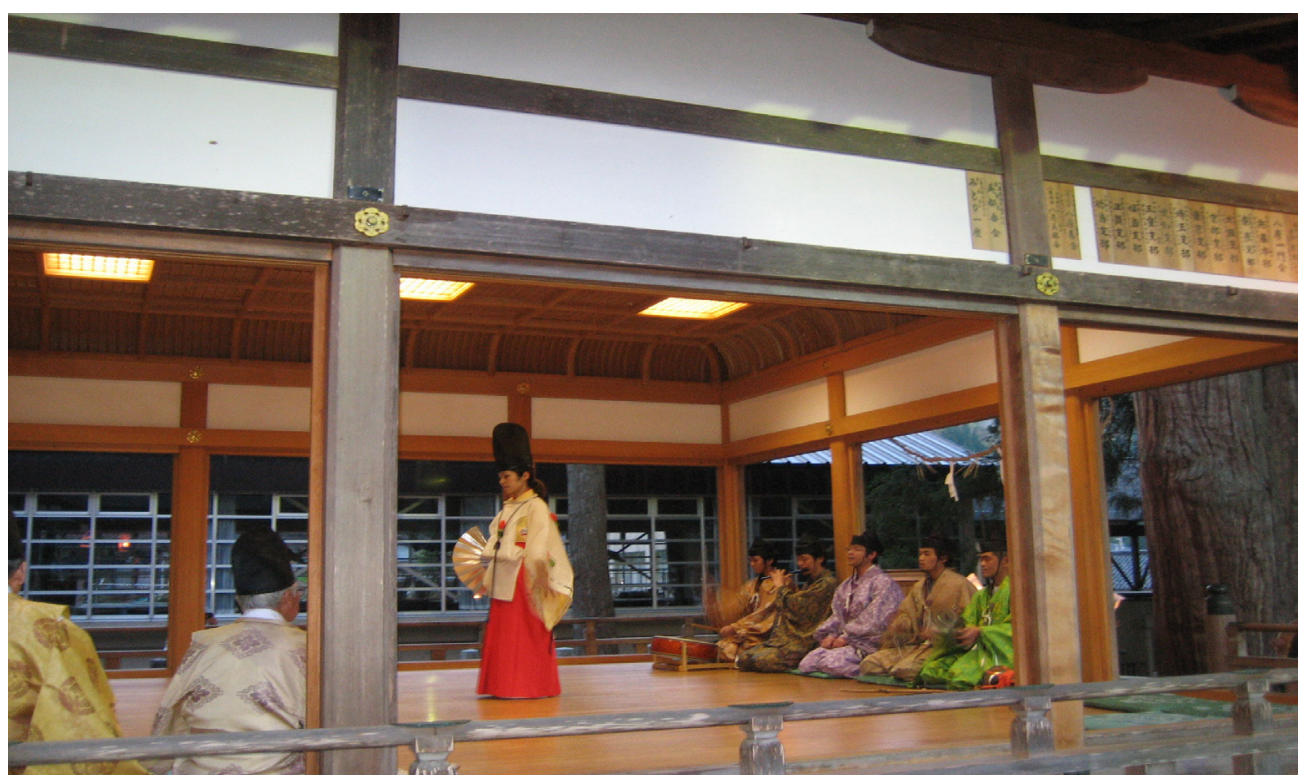

Slike 6-12: Pomladanski festival: po koncu levjega plesa shishi mai in procesije, s katero se daritev prinese v svetišče Hakusangu, se Kaguro mai izvede v svetišču; občinstvo sestavljajo lokalni ljudje. (Vir: Klara Hrvatin)

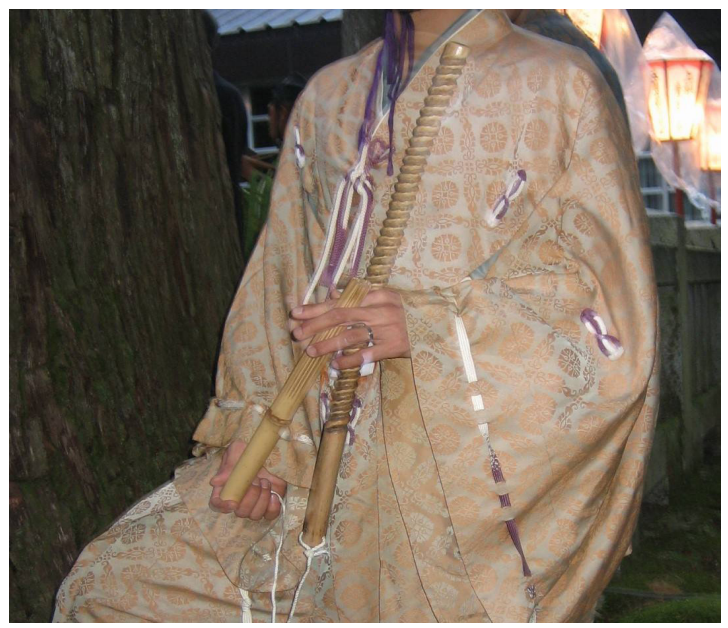

Slika 13: Upoštevajoč legendo, po kateri so rojstni kraj Kagure mai poselili pobegli bojevniki klana Taira, je združenje Kokiriko uta hozonkai privzelo kostume v slogu 12. stoletja. Na fotografiji zgoraj (slika 12) lahko vidimo običajni razpored glasbil, od leve proti desni: taiko, shinobue, pevec, nato pa sledita bōzasara in dōbyōshi. Na fotografiji je izvajalec na glasbilu bōzasara ali surizasara. (Vir: Klara Hrvatin) 
Pojem »lokalnosti« ima v tej regiji še en poseben vidik. Kraj, obkrožen s strmimi gorskimi pobočji, pozimi pa pokrit z globoko snežno odejo, je dolgo slovel kot nekakšna skrita oziroma neraziskana vas. Te okoliščine so se začele spreminjati leta 1930, ko se je začela gradnja cest in jezov ter električne napeljave. Šele razmeroma pozno, v času od izgradnje tunela leta 1984 in nazadnje $z$ gradnjo avtocestne povezave leta 2001 (五筒山インターチェンジ), so kraj povezali s soseščino in mesti, kot so Toyama, Kanazawa in druga (Misumi 1992, 2-3). Prav tako je k prepoznavnosti pripomogla razglasitev nekaj krajev v regiji za kulturno dediščino v letu 1995. Na ta način se je regija počasi odprla v svet in se povezala s preostalim delom države. To je tudi eden od pomembnejših razlogov, zakaj se tukajšnje ljudske pesmi še naprej prenašajo znotraj vasi in zakaj so ostale na nek način nedotaknjene od zunanjih vplivov (Sasara wa mado 2008). Združenje se torej izrazito identificira s svojo lokacijo.

Ga. Yamazaki, katere družina ima pomembno vlogo pri ohranjanju ljudskih pesmi in drugih živečih tradicij $\mathrm{v}$ regiji in ki je poleg tega tudi zaposlena $\mathrm{v}$ turističnem informacijskem centru v Gokayami ter ima o ljudskih pesmih Gokayame veliko neprecenljivega znanja, pove, da so se $\mathrm{v}$ preteklosti prebivalci vasi Kaminashi pozimi znašli v objemu s snegom pobeljenih gora in tako preživeli zimo kot »medvedje med svojim zimskim spanjem v brlogih« (Yamazaki, osebno sporočilo avtorici 31. julija 2007). Takrat ni bilo slavnosti ali plesov; dneve so preživljali v hišah, pokritih s snegom. Ko se je ta končno stalil, so lahko ponovno obiskali sosede, včasih so koga našli tudi mrtvega, saj je nekaterim čez zimo zmanjkalo hrane. Obenem so se številni ljudje, ki so delali v oddaljenih krajih, spomladi vrnili domov (ibid.). Te zgodbe so med ljudmi še vedno prisotne in na njih temelji pomen spomladanskega festivala Haru matsuri (glej slike 6-12), ki poteka od 26. do 27. aprila in je posebnega pomena za prebivalce Kaminashija. V nasprotju s festivalom Kokiriko je ta slavnost lokalne in ne turistične narave.

Kot regija, ki je dobro znana po hišah v slogu gasshō-zukuri, h katerimi privabljajo turiste, poskušajo prebivalci teh krajev opozoriti nase in obuditi tudi ljudske običaje. Ti dve posebnosti se lepo dopolnjujeta in sta glavna turistična atrakcija; odražata kraj, iz katerega izvirata, in kažeta na izrazito krajevno pripadnost.

Skupine so amaterske in niso osredotočene na materialne koristi. Čeprav víasih obstajajo tudi izjeme.

Vsi člani so samouki, ki namenijo veliko prostega časa aktivnostim združenja hozonkai. Ne posvečajo se mu z namenom koristi ali dobička, ampak je bolj pomemben namen, da bi bil hozonkai čim bolj prepoznaven in spoštovan s strani obiskovalcev oziroma da bi imel boljši ugled v regiji. Če sploh, hozonkai lahko pridobi nekaj financ iz naslednjih virov: 
1. Aktivnosti, posvečene privabljanju turistov (kot turistična atrakcija): za jesenski festival Kokiriko združenje hozonkai širši publiki predstavi pesmi Kokiriko uta in Kagura mai (glej slike 3-5). Na festivalu najprej predstavijo pesem Kagura mai. Ta se kot sakralni ples odpleše potem, ko se darovanje bogovom v svetišču zaključi. Plesalka skupaj z glasbo nastopi obrnjena proti oltarju, pred slovesno pripravljeno in blagoslovnljeno hrano, ki je položena na mala lesena stojala. Isti dan zvečer lahko pesem Kagura mai ponovno slišimo. Tokrat ne $\mathrm{v}$ povezavi s sakralno vlogo same pesmi in plesa, kot smo jo lahko videli v svetišču, ampak odrske izvedbe v obliki skrbno organiziranega kulturnega dogodka. Ta, drugi del festivala je usmerjen bolj k privabljanju tako gostov iz sosednjih bližnjih regij kot tudi turistov od daleč. Ker je tu Kagura mai predstavljena bolj spektakularno, jo izvede več nastopajočih kot v svetišču: še ena plesalka in še en pevec (glej sliko 4). ${ }^{15}$

2. Nastopi združenj hozonkai po Japonski in $\mathrm{v}$ tujini - bozonkai je večkrat povabljen na gostovanja v različne kraje na Japonskem in v tujini (Amerika, Honolulu, Koreja, Rusija itn.) - sicer prinesejo nekaj prihodka organizaciji, vendar si v večini primerov krijejo stroške potovanja in druge izdatke kar sami.

3. Izdelovanje instrumentov (aktivnost »izdelovanja instrumentov«je bila znana tako v preteklosti kot sedanjosti) je eden glavnih poklicev v vasi Kaminashi in sosednji vasi Tamukae. Vse pogostejše so tudi delavnice izdelovanja inštrumenta sasara, ki se jih obiskovalci lahko udeležijo, prav tako pa se je v zadnjem času povečalo število video vsebin $z$ napotki za izdelavo oz. igranje nanje.

Nagnjene so b konservativizmu in se upirajo spremembam v glasbi, besedilu, plesu, kostumih itn., čeprav so izjeme tudi na tem področju. Ko dejansko pride do sprememb, želijo imeti nad njimi nadzor. Na tej točki utegne priti do konflikta med združenji hozonkai in profesionalnimi urbanimi izvajalci.

Tabela 2 prikazuje vire Kagure mai v obdobju več kot šestdesetih let, od njene prve izvedbe leta 1952 do sedanjih posnetkov. Razvidno je, da je vse oblike ohranjanja pesmi in plesa Kagura mai izvedlo združenje Kokiriko uta bozonkai. Iz analize zbranih podatkov o pesmi Kagura mai $i^{16}$ lahko zaključimo, da se je skozi leta pesem standardizirala - bodisi glede glasbil, oblike ali ritma. Kar se tiče same funkcije pesmi, so po drugi strani vidne spremembe v njeni uporabi; njena funkcija ljudske upodabljajoče umetnosti se prepleta s turističnimi in

15 Poleg Kokiriko uta hozonkai se je na odru predstavilo še pet združenj (od tega štiri ohranjajo ljudske pesmi iz regije Gokayama), vse s svojimi lokalnimi pesmimi in plesi. To so Osayobushiya hozonkai ( 小谷麦屋節保存会), Ecchü Gokayama Mugiya-busi hozonkai (越中五箇山麦屋節保存会), Ecchu u Gokayama min'yō hozonkai (越中五箇山民謡保存会), Ecchü Yaoowara hozonkai (越中八尾おわら 保存会), Ecchū Gokayama Kokiriko uta hozonkai (越中五箇山こきりこ唄保存会).

O sami analizi več v Hrvatin 2010. 
folklornimi dogodki. Postala je del odrskega nastopa ali tako imenovane odrske ljudske pesmi (sutēji min'yō).

Tabela 2: Primerjava dokumentacije o načinu obranjanja Kagure mai od 1952 leta do danes

\begin{tabular}{|c|c|c|c|c|c|}
\hline Predstavniki virov & Namen & Pevci in glasbila & Ples & Prostor & $\begin{array}{l}\text { Način } \\
\text { ohranitve }\end{array}$ \\
\hline $\begin{array}{l}\text { Antologija japonskih } \\
\text { ljudskih pesmi (1952) } \\
\text { (日本民謡大鑑) } \\
\text { Kokiriko uta hozonkai }\end{array}$ & $\begin{array}{l}\text { zbiranje } \\
\text { ljudskega } \\
\text { blaga s } \\
\text { strani } \\
\text { NHK }\end{array}$ & $\begin{array}{l}\text { pevec, flavti (2), } \\
\text { male bakrene činele, } \\
\text { boben taiko, } \\
\text { bambusove palčke } \\
\text { kokiriko no take } \\
\text { (1. verz) }\end{array}$ & / & Gokayama & $\begin{array}{l}\text { transkripcija } \\
\diamond \text { avdio }(\mathrm{CD}) \\
\text { opisni vir }\end{array}$ \\
\hline $\begin{array}{l}\text { Ecchū Gokayama Min'yō } \\
\text { minbu hozondan rengōkai } \\
\text { (1974) } \\
\text { (越中五箇山民謡民舞保 } \\
\text { 存団連合会) } \\
\text { Kokiriko uta bozonkai }\end{array}$ & $\begin{array}{l}30 . \\
\text { obletnica } \\
\text { združenja }\end{array}$ & $\begin{array}{l}\text { pevca (2), flavti (2), } \\
\text { male bakrene činele, } \\
\text { boben taiko, strgalo } \\
\text { bözasara } \\
\text { (3.in 4. verz) }\end{array}$ & $\begin{array}{l}\text { dve } \\
\text { plesalki }\end{array}$ & Gokayama & $\diamond \mathrm{DVD}$ \\
\hline $\begin{array}{l}\text { Ljudske pesmi iz } \\
\text { Gokayame } \\
\text { (2002) } \\
\text { (五箇山の民謡, } \\
\text { Gokayama no minyō) } \\
\text { Kokiriko uta bozonkai }\end{array}$ & & $\begin{array}{l}\text { pevec, flavta, } \\
\text { male bakrene činele, } \\
\text { boben taiko, strgalo } \\
\text { bözasara } \\
(1 . \text { in } 2 \text {. verz) }\end{array}$ & & & $\diamond \operatorname{avdio}(\mathrm{CD})$ \\
\hline $\begin{array}{l}\text { Kokiriko matsuri (2007) } \\
\text { Kokiriko uta hozonkai }\end{array}$ & $\begin{array}{l}\text { a) del } \\
\text { festivala } \\
\\
\text { b) } \\
\text { turistična } \\
\text { atrakcija }\end{array}$ & $\begin{array}{l}\text { pevec (1), flavta (1), } \\
\text { male bakrene činele, } \\
\text { boben taiko, strgalo } \\
\text { bözasara } \\
(1 . \text { in } 3 . \text { verz) } \\
\text { pevec (2), flavta (2), } \\
\text { male bakrene činele, } \\
\text { boben taiko, strgalo } \\
\text { bözasara } \\
(1 . \text { in } 3 . \text { verz) }\end{array}$ & $\begin{array}{l}\text { ena } \\
\text { plesalka }\end{array}$ & Gokayama & $\begin{array}{l}\diamond \text { video } \\
\text { posnetek }\end{array}$ \\
\hline $\begin{array}{l}\text { Kokiriko uta hozonkai } \\
\text { (Haru matsuri) } \\
\text { (2008) } \\
\text { Kokiriko uta hozonkai }\end{array}$ & $\begin{array}{l}\text { del } \\
\text { festivala }\end{array}$ & $\begin{array}{l}\text { pevec (1), flavta (1), } \\
\text { male bakrene činele, } \\
\text { boben taiko, strgalo } \\
\text { bözasara } \\
(1 . \text { in } 2 \text {. verz) }\end{array}$ & $\begin{array}{l}\text { ena } \\
\text { plesalka }\end{array}$ & Gokayama & $\begin{array}{l}\diamond \text { video } \\
\text { posnetek }\end{array}$ \\
\hline
\end{tabular}

Na začetku delovanja je Kokiriko uta hozonkai določil, katero pesem, besedilo, ples in izvedbeni kostum bo ohranjal. Pravila združenja bozonkai določajo, da mora 
ohranjati pesmi v takšni obliki, kot so bile prenesene od prednikov izvajalcev. Vaščani se zavedajo, da mora biti pesem ohranjena $v$ avtentični obliki ali »zaprto brez sprememb « (kar avtorica tega članka imenuje koncept »zaprte škatle « ${ }^{17}$ ), čeprav je težko oz. skoraj nemogoče peti pesem na enak način, kot so se je naučili od svojih predhodnikov. Vodja urada združenja Iwasaki Kihei pravi, da je to v protislovju s samim ohranjanjem pesmi, saj »omejuje oz. ubije pesem« (Iwasaki Kihei, v pogovoru $\mathrm{z}$ avtorico, april 2008). Zelo rad bi, da bi se pravila združenja spremenila, tako da ne bi izvajali pesmi »le na določen način« (ibid.). Poudaril je tudi, da je pesem v vsakem primeru, če želijo ali ne, izpostavljena določenim spremembam. ${ }^{18}$

\section{Člani so pogosto zelo stari.}

Številna združenja hozonkai so bila osnovana v petdesetih in šestdesetih letih 20 . stoletja $z$ namenom obuditi vaško tradicijo, ki je zamrla $v$ tridesetih in štiridesetih letih 20. stoletja. Učitelji so zato običajno precej stari. Mlajše generacije je težko navdušiti nad lokalnimi ljudskimi pesmimi. Veliko lažje jih je privabiti, če je zraven še živahen ples.

Člani združenja Kokiriko uta hozonkai so starejši. Če se ozremo v zgodovino njegovih predsednikov (Mr. Takakuwa je bil leta 1951 imenovan kot prvi predsednik) kot tudi članov upravnega odbora, so vsi starejši in skoraj v vseh primerih nastopijo funkcijo predsednika v poznejših letih. Čeprav po besedah Kunitake Ōseija, ki je nedavno postal novi predsednik združenja, mladi prav tako zavzeto delujejo in pomagajo v okviru združenja (Sasara wa mado 2008). Preseneča tudi dejstvo, da populacija v vasici Kaminashi po besedah vaščanov v zadnjih časih narašča, kar pomeni, da se bo tradicija združenja hozonkai lahko nadaljevala tudi z mlajšimi generacijami.

Združenje Kokiriko uta hozonkai je bilo ustanovljeno, da bi obudilo tradicijo vasice, ki je poniknila v preteklosti. V viru Kokiriko: Njegov izvor in zgodovina (Kokiriko 2002), ki natančno opisuje začetke in delovanje združenja, je zapisano, da naj bi pesem in ples Kokiriko obstajala že 1400 let. Ko naj bi že skoraj poniknila v pozabo, naj bi pesnik Saijo Jaso (西条八十, 1892-1970) po naročilu časopisne družbe Ōsaka Mainichi leta 1930 obiskal Gokayamo in spraševal po pesmi. Zanjo naj bi slišal iz dela Skrivnostne zgodbe severnih dežel (奇談北 国巡杖記, Kidan hōkoku junjōki) Yanagite Kunia, začetnika japonske etnologije (Kokiriko 2002). Ker pesmi nihče ni poznal, se je poslovil brez kakršnihkoli informacij. Pozneje je ugotovil, da veliko ljudi pozna to pesem, vendar ne pod imenom Kokiriko. Čez nekaj časa je eden od vaščanov iz vasi Kaminashi,

17 Več v Hrvatin 2010.

18 Intervju je bil opravljen na njegovem domu (vasica Kaminashi Tairamura, 27. aprila 2008). Tam ima poleg male trgovine s tōfujem in sakejem malo pisarno, kjer hrani dokumente o združenju bozonkai. 
Takakuwa Takachika (高桑敬親), slišal zgodbo in začel raziskovati pesem Kokiriko. Imel naj bi zelo pomembno vlogo pri obujanju plesa in pesmi Kokiriko (Kokiriko 2002, 14-16). Zanimivo je tudi dejstvo, da je bil Takakuwa Takachika prvi predsednik združenja Kokiriko uta hozonkai ob njegovi ustanovitvi leta 1951 in mu je predsedoval prvih enaindvajset let.

Tudi Kagura mai ima nejasno zgodovino. V Antologiji japonskih ljudskib pesmi je zelo skromno opisana, izvajali naj bi jo pod imenom Maimai. Glede na pričevanja tako ljudi kot tudi odgovornih za hozonkai, obstaja o samem prenosu pesmi Kagura mai premalo informacij. Gospa Yamazaki razloži, da Maimai izvajajo med festivali in slavnostmi (na primer na zabavi, ki sledi poroki: stari in mladi, moški in ženske se vsi vrtijo v krogu), vendar je znana kot pesem Osayo-bushi. Natančneje: po drugi svetovni vojni naj bi ljudje začeli peti besedilo Osayo-bushi z melodijo Maimai. Ljudje, ki poznajo besedilo Maimai, so zdaj že izjemno redki. Sprva naj bi ga poznalo 40-50 ljudi, danes pa kvečjemu 10-20. Poleg tega se na Maimai z melodijo Kagure mai skoraj več ne pleše (Yamazaki, e-pošta avtorici, 31. julija 2007).

Zanimivi so tudi komentarji Iwasakija, ki zatrjuje oz. odkriva, da je Maimai postala Osayo-bushi, za katero skrbi drugo združenje, medtem ko naj bi pesem Kagura mai preprosto ustvaril Takakuwa, zanjo priredil besedilo (vse razen prve kitice) in ji dodal tudi glasbila, ki naj jih v osnovi ne bi bilo. Kot takšna naj ne bi imela več nobenih podobnostih ali povezav z Maimai, tako da jo kot član združenja zelo nerad izvaja ( $v$ pogovoru $\mathrm{z}$ avtorico, april 2008).

Verjetno ni vse tako preprosto, kot se sliši. Iwasaki je mnenja (ibid.), da nekaj v tej zgodbi manjka oziroma bi terjalo nadaljnje raziskave. Predvsem ostaja nejasno, kako se je stara tradicija (ljudska pesem Kokiriko in Kagura mai kot tudi njeni prevzeti kostumi) prenesla $\mathrm{v}$ sedanjost. To vprašanje je povezano $\mathrm{z}$ verjetnostjo, da hozonkai do neke mere ne prenaša starodavno oživljene pesmi Kagura mai in Kokiriko uta, ampak namesto te kaže na možnost primera »izumljene tradicije ${ }^{19}$

Člani pogosto upajo, da bo njihova priljubljena pesem (ali več pesmi) dosegla vidnost na nacionalni ravni. Hkrati pa se člani velikokrat pritožujejo nad tem, kako neizogibno je, da profesionalni izvajalci njihove pesmi na taǩsen ali drugačen način spremenijo.

Člani stremijo $\mathrm{k}$ slovesu svoje pesmi in tekmujejo s prepoznavnostjo združenj hozonkai v svoji okolici. Tako kot na svoje nastope na Japonskem (kjer

19 Tu se avtorica sklicuje na pojem »izmišljene tradicije« (Hobsbawm 1983, 1) iz dela Invented traditions, v katerem je pojasnjeno, da se za večino starih tradicij (ali tistih, ki se imajo za stare) pogosto izkaže, da so po svojem izvoru mlajše in lahko tudi izumljen konstrukt. 
nastopajo na dogodkih, kot so državna srečanja ljudskih pesmi in plesov, ki jih producira NHK, Festival domačih pesmi (Furusato no uta matsuri) ali Venček ljudskih pesmi (Min'yō baraetì), Festival ljudskih pesmi in plesov iz Gokayame itn.), so ponosni tudi na nastope na drugih celinah. Predvsem leta 1974 so se pogosto udeležili mednarodnih prireditev v Ameriki (Philadelphia, Denver, Los Angeles, San Francisco) in na Havajih ter v naslednjih letih tudi v Koreji in Rusiji (Kokiriko 2002, 14-16), kar tudi potrjuje slednjo značilnost Hughesove opredelitve.

Gospod Iwasaki ni bil navdušen nad priredbo pesmi Kagura mai (priredbi za klavir in glas skladatelja Mamiye Michia ${ }^{20}$ ) in je trdil, da je izvedba, ki jo izvaja bozonkai, veliko boljša. Prav tako ga je zanimalo, ali je v zbirki še kakšna pesem, ki jo prav tako izvaja katero od združenj hozonkai (Iwasaki Kihei, v pogovoru z avtorico, april 2008).

\section{Posebnosti združenja Kokiriko uta hozonkai}

Združenje Kokiriko uta hozonkai ustreza sliki značilnosti združenj hozonkai, kot jih opredeli Hughes, kaže pa tudi na posebnosti. $Z$ drugimi besedami, združenje Kokiriko uta hozonkai je resnično "lokalna organizacija $\mathrm{z}$ maloštevilnimi člani, ki niso profesionalci ali materialno usmerjeni in imajo $\mathrm{v}$ splošnem precej konservativen odnos do glasbe, ki jo ohranjajo« (Hughes 2008a), vseeno pa so vidna odstopanja $\mathrm{v}$ tem združenju, po katerih se razlikuje od generične slike opredelitve združenj, kot jih je podal Hughes. Odstopanja so:

1. Izrazit koncept lokalnosti: Seveda je ena od značilnosti združenja Kokiriko uta hozonkai pripadnost lokalnosti oz. domačemu kraju (t. i. koncept »furusato«), kot je to v primeru večine združenj hozonkai. Kar je pri tem treba poudariti, je dejstvo, da je glede na dolgo zgodovino izolacije vasice Kaminashi iz Tairamure zaradi njene geografske lege koncept lokalno osnovanega združenja močnejši kot v drugih združenjih hozonkai.

2. Prizadevanje za spremembe: Čeprav združenje Kokiriko uta hozonkai spoštuje direktivo zakona o varstvu kulturne dediščine, $\mathrm{v}$ svojih pogledih ni popolnoma konservativen. Pravzaprav člani združenja želijo, da se zakon v prihodnosti revidira tako, da bo dovoljeval več kot samo ohranjanje same pesmi.

Prav tako zanimivo oz. kontradiktorno je dejstvo, da se v okviru standardizacije (bodisi oblike, ritma, teksta, njenih instrumentov itn.), s katero se glede na zakon združenje trudi ohranjati pesmi Kokiriko in Kagura mai, pesem še vedno prenaša ustno. Nikakor ni smiselno vztrajati, da mora biti ljudska pesem, ki se prenaša

20 Za podrobnosti glej Hrvatin in Ito 2009. 
ustno, zapeta v »fiksirani« obliki. Poleg tega lahko pesem Kagura Mai izvaja (ter ohranja) samo združenje Kokiriko uta hozonkai in ne sme biti peta na drugačen način, kot ga določa samo združenje.

3. Vprašljivo "prenašanje kulture«: Ta točka ni neposredno povezana s Hughesovimi značilnostmi združenj, ampak kaže na nove poteze združenja Kokiriko uta hozonkai. Povezana je z mislijo, da združenje Kokirko uta hozonkai ne prenaša starodavne oživitve pesmi Kagura mai (in Kokiriko uta), ampak namesto te kaže na možnost prenašanja t. i. »izumljene tradicije«. Do osvetlitev tega vprašanja prenosa starodavne tradicije je prišlo $v$ intervjuju $\mathrm{z}$ vodjo urada združenja Iwasakijem, sledimo pa mu lahko tako $\mathrm{v}$ zgodovinskih zapisih kot tudi $\mathrm{v}$ študijah o združenjih hozonkai.

\section{Literatura}

Agency for Cultural Affairs. 2015. Cultural Properties for Future Generations: Outline of the Cultural Administration of Japan. Tokyo: Cultural Properties Department. Dostop 23. avgust 2018. http://www.bunka.go.jp/english/report/ publication/pdf/pamphlet_en_03_ver04.pdf.

Ecchū Gokayama Kokiriko uta kiroku 越中五ヶ山筑子唄記録 (Zapisi o pesmi Kokiriko uta iz Ecchū Gokayame). 1974. Kaminashi: Ecchū Gokayama Kokiriko Uta Hozonaki.

Ecchū Gokayama no Dentō Geinō no Chōsa 越中五箇山の伝統芸能の調査 $(R a-$ ziskava o tradicionalnih uprizoritvenih umetnosti v Ecchü Gokayami). 1993. Tokyo: Meiji daigaku Ōkuma seminar.

Embree, F. John. 1944. Japanese Peasant Songs. Virginia: William Byrd Press.

Fujita, Takanori. 2002. »Continuity and Authenticity in Traditional Japanese Music. V The Garland Encyclopedia of World Music, zv. 7, uredili Robert C. Provine, Yosihiko Tokumaru in J. Lawrence Witzleben, 767-72. New York: Routledge.

Groemer, Gerald. 1994. „Fifteen Years of Folk Song Collection in Japan: Reports and Recordings of the „Emergency Folk Song Survey' " Asian Folklore Studies 53: 199-209.

Groemer, Gerald. 2002. "Japanese Folk Music.«V The Garland Encyclopedia of World Music, zv. 7, uredili Robert C. Provine, Yosihiko Tokumaru and J. Lawrence Witzleben, 599-606. New York: Routledge.

Gokayama no Min'yō 五䈯山の民謡 (Ljudske pesmi iz Gokayame). 1980. Gokayama: Gokayama Sanson research center.

Hobsbawm, Eric. 1983. »Introduction: Inventing Tradition.«V Inventing Tradition, uredila Erich Hobsbawm in Terence Ranger, 1-14. Cambridge: Cambridge University Press. 
Hrvatin, Klara in Nobuhiro Ito. 2009. „Mamiya Michio shi e no intabyū : sakkyokuka wa 'min'yō' ni nani ga dekiruka? 間宮芳生氏へのインタビ ュー：作曲家は「民謡」に何ができるか？(Interview with Michio Mamiya: A Composer Devoted to the Folk).«Asian and African Studies XIII (3): 107-115.

Hrvatin, Klara. 2010. »The Japanese Folk Song Kagura Mai: To Be or Not to Be Preserved.«V Abstracts E preliminary papers, IFYM 2010 Organizing Committee in The Musicological Society of Japan, 111-25. Yokohama: Keio University.

Hughes, W. David. 2007. „Folk Music: From Local to National to Global.«V The Ashagate Research Companion to Japanese Music, uredila Alison Tokita in David W. Hughes, 281-302. Aldershot: Ashagate Publishing Limited.

- 2008a. Traditional Folk Song in Modern Japan. Sources, Sentiment and Society. London: Global Oriental Ltd.

—. 2008b. Japanese Folk Song. Seminar at the International Research Center for Japanese Studies. Kyoto: November 11, 2008.

-. 2008c. Traditional Folk Song in Modern Japan. Lecture at the International Research Center for Japanese Studies. Kyoto: November 6, 2008.

Kakiuchi, Eiko. 2014. „Cultural Heritage Protection System in Japan: Current Issues and Prospects for the Future."National Graduate Institute for Policy Studies. Tokyo: Grips. Dostop 31. avgust 2018. http://www.grips.ac.jp/r-center/ wp-content/uploads/14-10.pdf.

Kato, Tomiko. 2002. "Transmission of Traditional Japanese Music.«V The Garland Encyclopedia of World Music, zv. 7, uredili Robert C. Provine, Yosihiko Tokumaru and J. Lawrence Witzleben, 773-76. New York: Routledge.

Kobinata, Hidetoshi. 2007. „Policies\&Actions. "Asia-Pacific Database on Intangible Cultural Heritage (ICH). Dostop 31. avgust 2018. http://accu.or.jp/ich/en/ policies/C_JPN.html .

Koizumi, Fumio, Tokumaru Yoshihiko in Yamaguchi Osamu, ur. 1977. Asian Music in an Asian Perspective. Tokyo: The Japan Foundation.

Koizumi, Fumio. 1977. Nibon no Oto: Sekai no Naka no Nibon Ongaku日本の音: 世界の中の日本音楽 (Zvoki Japonske: Japonska glasba v svetu). Tokyo: Seido Sha.

Kokiriko: Sonoyurai to rekishihokaこきりこ:その由来と歴史ほか (Kokiriko:njen izvor in zgodovina). 2002. Kaminashi: Ecchūgokayama Kokiriko Hozonkai.

Komoda, Haruko in Nogawa Mihoko. 2002. »Theory and Notation in Japan.«V The Garland Encyclopedia of World Music, zv. 7, uredili Robert C. Provine, Yosihiko Tokumaru and J. Lawrence Witzleben, 565-84. New York: Routledge.

Kurosaka, Tomiji. 1977. »Kokiriko Uta."Kikan Högaku 11.

Lancashire, Terence. 2011. An Introduction to Japanese Folk Performing Arts. Farnham, Burlington: Ashgate Publishing, Ltd. 
Malm, William. 2000. Traditional Japanese Music and Musical Instruments. Tokyo: Kodansha International.

Mamiya, Michio. 1998. „Notes on the Japanese Folk Song Collection for Voice and Piano." Fontec Inc. Tokyo: FOCD3481.

—. 2001 (1975). Japanese Folk Song Collection. Tokyo: Zenon music.

Misumi, Haruo. 1992. «Notes in Gokayama no Min'yō.« CD Gokayama no Min'yō. Gokayama: Gokayama kankō kyokai.

Nettl, Bruno. 1985. The Western Impact on World Music. New York: Schrimer Books.

- 2005. The Study of Ethnomusicology (Thirty-one Issues and Concepts). Chicago: University of Illinois Press.

Nihon Hōsō Kyōkai (Japan Broadcasting Co.), ed. Nibon min'yō taikan (Chūbu hen) 日本民謡大鑑 (中部篇) (Antologija japonskib ljudskib pesmi (Regija Chūbu)). 1993 (1952). Tokyo: Nihon hōsō kyōkai.

Ono, Sokyo. 1999. Shinto: The Kami Way. Tokyo: Charles Tuttle Company.

Sasara wa mado no moto ni aru (217), Ikiru ikiru 第21回ささらは空の許にあ る、生きるx 2 (Sasara pod oknom (217), Ikiru Ikiru 21). 2008. Toyama shi: Kitanihon broadcasting.

Setsuritsu Sanjü Nen Kinenshi 設立三十年記念誌 (Spominska publikacija posvečena 30. obletnici ustanovitve). 2004. Ecchū Gokayama min'yō minbu hozonkai dantai rengōkai.

Shimosako, Mari. 2002. »Philosophy and Aesthetics. "V The Garland Encyclopedia of World Music, zv. 7, uredili Robert C. Provine, Yosihiko Tokumaru and J. Lawrence Witzleben, 554-55. New York: Routledge.

Sukeshige, Takehisa, Researching group of Gokayama Area. 2018. »Tōkaihokurikujidōshadō kaitsū ni tomonau Gokayama kankō no hen'yō 東海北陸自動 車道開通に伴う五䇢山観光の変容 (Impacts of the Tökai-Hokuriku Expressway on Tourism in Gokayama).« Dostop 13. september 2018. http://www.tuins.ac.jp/library/pdf/2006chiiki-PDF/sukeshigeetal.pdf.

Takakuwa, Takachika. 1973. Gokayama no min’yō-shu 五箇山の民謡集 (Zbirka ljudskih pesmi iz Gokayame). Kaminashi: Toyama sugaki.

—. 1994. Kodai Minyo: Kokirikono Kigenkō 古代民謡筑子の起原考 (Izvor starodavne ljudske pesmi Kokiriko). Toyama: Maki insatsu kabushikigaisha.

Tanabe, Hisao. 1973. Nibon no Gakki 日本の楽器 (Japonski instrumenti). Tokyo: Kashiwa shuppan.

Tanigaito, Kasuko. 2002. "Shinto Music."V The Garland Encyclopedia of World Music, zv. 7, uredili Robert C. Provine, Yosihiko Tokumaru and J. Lawrence Witzleben, 607-10. New York: Routledge. 